\title{
Influence of Drought Stress and Rehydration on Moisture and Photosynthetic Physiological Changes in Three Epilithic Moss Species in Areas of Karst Rocky Desertification
}

\author{
Chunlei Cong $\mathbb{D}^{1},{ }^{1}$ Tianlei Liu, ${ }^{1}$ and Xianqiang Zhang $\mathbb{D}^{2}$ \\ ${ }^{1}$ Anshun University, Anshun 561000, China \\ ${ }^{2}$ Guizhou Police College, Guiyang 550005, China \\ Correspondence should be addressed to Chunlei Cong; congchunlei@163.com and Xianqiang Zhang; zhangxianqiang@126.com
}

Received 3 October 2021; Accepted 17 November 2021; Published 10 December 2021

Academic Editor: $\mathrm{Hu} \mathrm{Li}$

Copyright (C) 2021 Chunlei Cong et al. This is an open access article distributed under the Creative Commons Attribution License, which permits unrestricted use, distribution, and reproduction in any medium, provided the original work is properly cited.

\begin{abstract}
The drought resistance mechanism of typical mosses in the karst area was studied, and the water and photosynthetic physiological adaptation of mosses to karst environmental change was analyzed in this paper, which provided the basis for the restoration and control of karst rocky desertification ecological environment. Three superior plants in the rocky desertification area of Guizhou province were selected; they are, respectively, Erythrodontium julaceum (Schwaegr.) Par., Barbula unguiculata Hedw., and Bryum argenteum Hedw. Results show that the three kinds of plant rock mosses of leaf water potential $(\Psi s)$, free water content $\left(V_{a}\right)$, total water content, and relative water content (RWC) decreased; bound water $\left(V_{s}\right)$, water saturation deficit (WSD), and $V_{s} / V_{a}$ ratio increased; transpiration rate (Tr) fell slightly, under drought stress. The physiological indexes of water have different degrees of recovery after rehydration. The total chlorophyll content shows a trend of first increasing followed by falling and then rising. RWC was negatively related to $q N$ and positively related to $F_{v} / F_{m}$, yield, ETR, and $q P$. After rewetting, the fluorescence parameters are returned to average level under mild-to-moderate stress. At the same time, it is hard to get back to the control level under severe pressure. The water use efficiency (WUE) decreased with stress and recovered to different degrees after rehydration.
\end{abstract}

\section{Introduction}

Biological crusts are complex complexes formed by cementation of cryptogam plants (such as algae, lichens, and bryophytes), soil microorganisms, and surface soil particles. The crust is an essential component of the ecological system in arid and semiarid regions. The karst plateau area in south China is located in the subtropical monsoon humid climate zone. In this area, the soil layer is shallow, the bedrock is exposed, the infiltration coefficient of atmospheric precipitation is large, and the leakage is serious. This area is prone to the formation of karst seasonal arid habitat characteristics, such as rain logging and sunny drought [1]. This drought is not caused by dry air but by the growth of lichen on the limestone surface, caused by a sharp seepage of precipitation. The water required for long-term maintenance inevitably causes different physiological responses of bryophytes to drought and rehydration, such as the physiological regulation of bound water together with free water. Changes in leaf transpiration and photosynthetic rates may be a physiological adaptation mechanism of bryophytes to harsh karst conditions, but there is little literature in the area.

Bryophytes are highly drought-resistant. Previous studies primarily focused on the characteristics and mechanism of drought tolerance, such as the morphological variation in mosses in the process of drought resistance $[2,3]$, physiological and biochemical mechanisms $[4,5]$, and modes of reproduction $[6,7]$. Mosses can tolerate physiological water loss and physiological tissues with long-term tolerance to drought and can quickly resume various physiological activities when water conditions improve $[8,9]$. In contrast to corresponding vascular plant, water potential of drought-tolerant moss is much lower. The obvious water potential gradient established between plants 
and the environment can accelerate the movement of water [10]. Some researchers have studied the water relationship and drought resistance of bryophytes using thermocouple hygrometers and hygrometers from the $p-v$ curve, moisture relationship index, water potential, and hydraulic retention [11-14]. Some other researchers studied changes in the chlorophyll fluorescence of mosses $[15,16]$ and liverworts $[17,18]$ during dehydration and rehydration by using the chlorophyll fluorescence technique. Csintalan analyzed chlorophyll fluorescence of three moss species under dryingwetting actions; the chlorophyll fluorescence parameters of moss plants would remain relatively constant as relative water content within a certain range. Similarly, chlorophyll fluorescence parameters, that is, $F_{v} / F_{m}, F_{m}$, ФPS II, and $q N$, reduced with the loss of water; $\Phi$ PS II and $F_{v} / F_{m}$ after rehydration could gradually return to normal levels at short notice [19]. Domestic researchers (Chinese) found that Grimmia pilifera P. Beauv.'s chlorophyll fluorescence parameters have relatively low water content threshold value in dehydration and rehydration. At extremely low temperatures in winter and high-temperature dry environment in summer, Mitt. in northwestern deserts will enter a dormant state through water loss. Furthermore, when the snow melts in the early winter and spring, Syntrichia caninervis Mitt. can rapidly recover fluorescence activity [20]. Zhang studied Barbula fallax Hedw., Stereodon taxirameus Mitt., and Bryum argenteum in a drought environment in karst areas of Guizhou and believed karst bryophytes could cope with arid karst environment in the process of metabolism and photosynthesis [21, 22].

Moss plays an essential role in forest ecosystems, because it is an irreplaceable component in moisture, soil, and water conservation and improvement in the ecological microenvironment [23]. Existing research studies on the relationship between drought resistance and water content in Syntrichia caninervis have focused on extreme arid desert areas without rainfall. However, there are few studies on the changes of water physiology and photosynthetic characteristics of bryophytes in drought and rehydration. Therefore, the typical epilithic mosses, namely, Barbula unguiculata Hedw., Erythrodontium julaceum (Schwaegr.) Par., and Bryum argenteum Hedw., were selected and used to study the changes of the physiological and photosynthetic characteristics after drought stress and rehydration. This provides the scientific basis for in-depth understanding of the adaptive characteristics of epilithic mosses to the environmental changes in karst and the restoration and control of ecological environments undergoing rocky karst desertification.

\section{Materials and Methods}

2.1. Study Materials. The crusted mosses for testing included Erythrodontium julaceum (Schwaegr.) Par., Barbula unguiculata Hedw. and Bryum argenteum Hedw. Erythrodontium julaceum (Schwaegr.) Par. is an interwoven type, which grows on the surface of stones; Barbula unguiculata Hedw. and Bryum argenteum Hedw. are cluster types, growing on rock surfaces. The study materials were collected from Chenqi Severe Rocky Desertification Area, Observation, and Research Station of Puding Karst Ecological System, Chinese Academy of Sciences. When the mean temperature is $25 \pm 1^{\circ} \mathrm{C}$, the samples could be gathered on sunny days.

2.2. Culture and Treatment with Material. According to the methods described by Zhang [24], drought stress treatment will not be repeated here. After $0,12,24,48$, and $72 \mathrm{~h}$ treatment, the determination of each index was repeated after $24 \mathrm{~h}$.

\subsection{Methods}

2.3.1. Water Physiological Index. Water content was measured by drying and weighing method. Relative water content and natural saturation deficiency were measured using expansion drying method. Leaf water potential was detected by drop flowing method. The above indexes were measured according to Edition 4 raised by Zhang [25]. Bound water and free water were detected by Weighing Method raised by Liu. [26].

$$
\begin{aligned}
\text { Natural water content }(\%) & =\frac{W_{f}-W_{d}}{W_{d}} \times 100, \\
\text { Relative water content }(\%) & =\frac{W_{f}-W_{d}}{W_{t}-W_{d}} \times 100, \\
\text { Natural saturation deficiency }(\%) & =\frac{W_{t}-W_{f}}{W_{t}-W_{d}} \times 100, \\
\text { Free water }(\%) & =\frac{\text { Natural fresh weight of tissue }- \text { Weight of tissue after immerse }}{\text { Bound water }(\%)} \times 100, \\
\text { Leaf water potential } P & =\text { RTIC, }
\end{aligned}
$$


where $P$ refers to atmospheric pressure (1 atmospheric pressure $=1.0133$ bar, $1 \mathrm{MPa}=10$ bar). $R$ refers to gas constant (0.0821). $T$ refers to absolute temperature $\left(T=273+t^{\circ} \mathrm{C}\right) . I$ refers to isotonic coefficient. Isotonic coefficient of sucrose is 1 . $C$ refers to concentration of isotonic solution.

2.3.2. Determination of Chlorophyll Fluorescence Activity. According to the method described by Bao [27], chlorophyll content is determined. Moss gametophytes with different treatments were maintained in the sample chamber for half an hour of dark adaptation. A portable pulse modulated chlorophyll fluorometer, PAM-2100 (Walz, Germany), is employed for detecting the maximum photochemical quantum yield $\left(F_{v} / F_{m}\right)$, initial fluorescence $\left(F_{0}\right)$, photochemical quenching $(q P)$, nonphotochemical quenching $(q N)$, yield (actual photosynthetic efficiency), $r$ ETR (electron transport rate), and other fluorescence parameters for all the labeled gametophytes, among which ФPSII $=\left(F_{m}{ }^{\prime}-F\right) / F_{m}{ }^{\prime}$, $q P=\left(F_{m}^{\prime}-F_{t}\right) /\left(F_{m}^{\prime}-F_{o}^{\prime}\right), \quad q N=\left(F_{m}-F_{m}^{\prime}\right) / F_{m}-F_{o}^{\prime}$, $F_{v} / F_{m}=\left(F_{m}-F_{0}\right) / F_{m}$, and ETR $=$ ФPS II (photosystem II) $\times$ PAR (photosynthetically active radiation intensity) $\times$ $0.84 \times 0.5$ [28]. This is repeated for six times to acquire average value. The physical meanings of parameters contained are as follows: real-time fluorescence yield $\left(F_{t}\right)$, maximum fluorescence $\left(F_{m}\right)$, variable fluorescence $\left(F_{v}\right)$, initial fluorescence yield under light $\left(F_{0}^{\prime}\right)$, and maximum fluorescence yield $\left(F_{m}^{\prime}\right)$.

2.4. Statistical Analysis. All of the experiments were implemented 5 times. SPSS 13.0 software was applied to process the data expressed as the mean \pm standard deviation of three independent experiments. Mapping was performed using Origin 8.0 and Microsoft Excel 2017 software.

\section{Results and Analysis}

3.1. Water Content, Free Water Content $\left(V_{a}\right)$, and Bound Water Content $\left(V_{s}\right)$ of Leaf Tissue. The water content of the epilithic mosses shows a gradually declining trend as stress increases. For Bryum argenteum Hedw., water content is down from $65.7 \%$ at the beginning to $48.2 \%$ after stress for $72 \mathrm{~h}$, falling by $26.6 \%$. Barbula unguiculata Hedw. decreased from $77.4 \%$ to $43.2 \%$ after stress for $72 \mathrm{~h}$, falling by $44.2 \%$. For Erythrodontium julaceum (Schwaegr.) Par., it is down from $84.2 \%$ to $48.6 \%$ after stress for $72 \mathrm{~h}$, falling by $42.3 \%$. Among the three, the declining range of Barbula unguiculata Hedw. is the highest. After $24 \mathrm{~h}$ of rehydration, each of the three moss species exhibits different degrees of recovery in water content, but they cannot restore to the control level in a short time. If the stress is higher, the degree of recovery is lower (Table 1).

It can be found from Table 1 that $V_{a}, V_{s}$, and $V_{s} / V_{a}$ of the three mosses are significantly changed with the aggravation of water stress, among which, $V_{s}$ and $V_{s} / V_{a}$ are increased and $V_{a}$ is decreased. After rehydration, all indexes restore to a certain degree. However, variance analysis shows that the difference is not significant. In this paper, after $72 \mathrm{~h}$ of stress, the indices for Bryum argenteum Hedw. are 1.31 and 1.41 for Barbula unguiculata Hedw. and 1.41 for
Erythrodontium julaceum (Schwaegr.) Par. After rehydration, the ratios slightly decrease.

3.2. Changes in Relative Water Content (RWC), Water Saturation Deficiency (WSD), and Leaf Water Potential (Øs) of Leaves. It can be seen from Table 1 that as stress increases, the RWC of each treatment shows a declining trend. For Bryum argenteum Hedw., RWC is down from $61.3 \%$ at the beginning to $33.1 \%$ after stress for $72 \mathrm{~h}$, falling by $46.0 \%$. For Barbula unguiculata Hedw., it is down from $67.4 \%$ to $39.7 \%$ after stress for $72 \mathrm{~h}$, falling by $41.1 \%$. For Erythrodontium julaceum (Schwaegr.) Par., it is down from $83.2 \%$ to $47.3 \%$ after stress for $72 \mathrm{~h}$, falling by $43.2 \%$. By comparison, the declining range of Bryum argenteum Hedw. is the highest, followed by Erythrodontium julaceum (Schwaegr.) Par., and that of Barbula unguiculata Hedw. is the lowest. WSD is up as stress increases. After $72 \mathrm{~h}$ of stress, WSD increases from $38.7 \%$ to 67.9\% for Bryum argenteum Hedw., from $32.6 \%$ to $60.3 \%$ for Barbula unguiculata Hedw., and from $16.8 \%$ to $52.7 \%$ for Erythrodontium julaceum (Schwaegr.) Par. This indicates that the responsiveness of epilithic mosses in karst to environmental change is different in long-term drought stress. After rehydration, RWC increases and WSD declines in varying degrees. This shows that epilithic mosses have a certain hysteresis effect against water stress in a short time. RWC and WSD of the three mosses have specific adaptability to the arid environment. In this paper, Erythrodontium julaceum (Schwaegr.) Par. has the smallest WSD at 16.8\% and Bryum argenteum Hedw. has the largest at $38.7 \%$. For WSD, the trend is Bryum argenteum Hedw.>Barbula unguiculata Hedw. > Erythrodontium julaceum (Schwaegr.) Par.

It can be found from Table 1 that, upon aggravation of water stress, water potential will be down in different degrees. For Bryum argenteum Hedw., it is down from $-1.65 \mathrm{MPa}$ at the beginning to $-8.16 \mathrm{MPa}$ after stress for $72 \mathrm{~h}$, falling by $-6.51 \mathrm{MPa}$; for Barbula unguiculata Hedw., water potential is down from $-0.05 \mathrm{MPa}$ at the beginning to $8.79 \mathrm{MPa}$ after stress for $72 \mathrm{~h}$, falling by $-8.74 \mathrm{MPa}$; for Erythrodontium julaceum (Schwaegr.) Par., it is down from $-0.03 \mathrm{MPa}$ to $-9.27 \mathrm{MPa}$ after stress for $72 \mathrm{~h}$, falling by -9.23 MPa. Erythrodontium julaceum (Schwaegr.) Par. has the highest declining range followed by Barbula unguiculata Hedw. and Bryum argenteum Hedw. has the lowest declining range (Figure 1). After rehydration, each moss plant has a different degree of recovery in water potential. It indicates that karst moss plants have stronger drought resistance and dewatering ability. Further exploration of the relationship between RWC and water potential (Figure 2) among the three mosses shows a slight difference. Water potential is decreased with decreasing RWC. A significant correlation exists between both of them $(P<0.05)$.

\subsection{Drought Stress and Rehydration Influence on the Photosynthetic Physiology and Ecology of 3 Epilithic Mosses}

3.3.1. Drought Stress and Rehydration Influence on Changes in Photosynthetic Pigments of 3 Epilithic Mosses. Table 2 







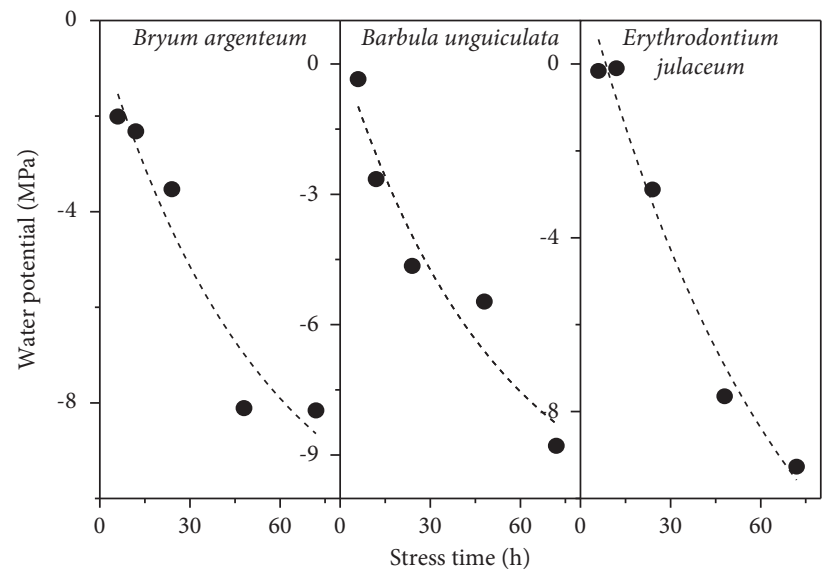

FIGURE 1: Effect of drought stress on water potential in three epilithic mosses.

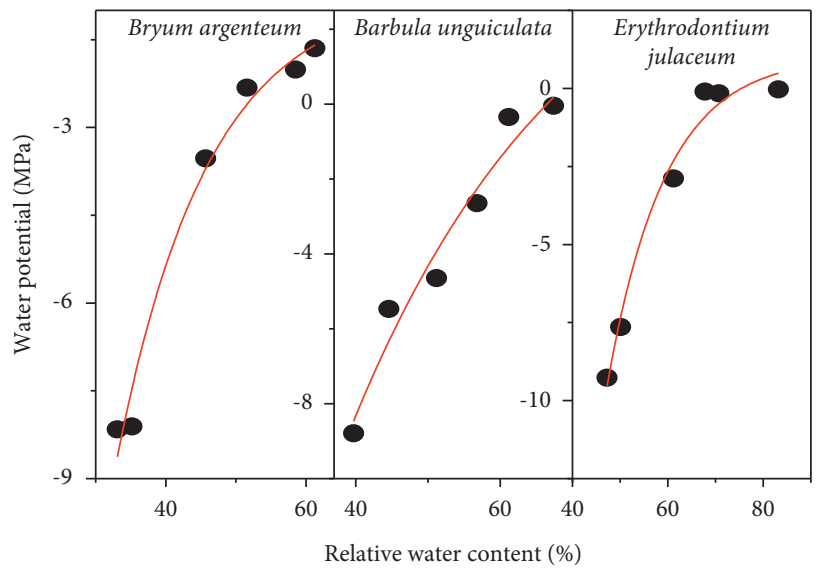

FIGURE 2: Relationship between water potential and RWC in three epilithic mosses during dehydration.

TABLE 2: The effect of drought stress and the replenishment on photosynthetic physiology indexes in three epilithic mosses. Erythrodontium julaceum (Schwaegr.) Par. with permission from [24]. Copyright 2016 open-access from Bangladesh botanical society.

\begin{tabular}{|c|c|c|c|c|c|c|c|c|c|}
\hline \multirow[t]{2}{*}{ Species } & \multirow[t]{2}{*}{ Treatment } & \multicolumn{2}{|c|}{ Chlorophyll a } & \multicolumn{2}{|c|}{ Chlorophyll b } & \multicolumn{2}{|c|}{$\begin{array}{l}\text { Transpiration }(\mathrm{mmol} \\
\left.\mathrm{H}_{2} \mathrm{O} \cdot \mathrm{m}^{-2} \cdot \mathrm{s}^{-1}\right)\end{array}$} & \multicolumn{2}{|c|}{$\begin{array}{l}\text { Net photosynthetic rate } \\
\quad\left(\mu \mathrm{mol} \mathrm{CO}{ }_{2} \cdot \mathrm{m}^{-2} \cdot \mathrm{s}^{-1}\right)\end{array}$} \\
\hline & & Stress & Rewatering & Stress & Rewatering & Stress & Rewatering & Stress & Rewatering \\
\hline \multirow{6}{*}{$\begin{array}{l}\text { Bryum argenteum } \\
\text { Hedw. }\end{array}$} & $\mathrm{CK}$ & $0.61 \pm 0.12$ & - & $0.28 \pm 0.04$ & - & $1.07 \pm 0.21$ & - & $15.19 \pm 1.02$ & - \\
\hline & 6 & $0.59 \pm 0.09$ & $0.57 \pm 0.08$ & $0.19 \pm 0.02$ & $0.24 \pm 0.05$ & $0.98 \pm 0.09$ & $0.65 \pm 0.12$ & 12.44 & $8.76 \pm 1.33$ \\
\hline & 12 & $0.58 \pm 0.11$ & $0.67 \pm 0.10$ & $0.21 \pm 0.03$ & $0.24 \pm 0.05$ & $0.97 \pm 0.12$ & $0.69 \pm 0.10$ & $10.65 \pm 0.69$ & $8.78 \pm 1.24$ \\
\hline & 24 & $0.43 \pm 0.06$ & $0.69 \pm 0.14$ & $0.20 \pm 0.02$ & $0.28 \pm 0.07$ & $0.99 \pm 0.20$ & $0.58 \pm 0.08$ & $7.51 \pm 0.77$ & $8.09 \pm 1.08$ \\
\hline & 48 & $0.72 \pm 0.12$ & $0.58 \pm 0.07$ & $0.34 \pm 0.05$ & $0.53 \pm 0.14$ & $0.88 \pm 0.16$ & $0.58 \pm 0.10$ & 6.26 & $8.74 \pm 1.21$ \\
\hline & 72 & $0.64 \pm 0.18$ & $0.68 \pm 0.08$ & $0.27 \pm 0.04$ & $0.32 \pm 0.12$ & $0.75 \pm 0.14$ & $0.62 \pm 0.13$ & & $8.10 \pm 1.11$ \\
\hline \multirow{6}{*}{$\begin{array}{l}\text { Barbula unguiculata } \\
\text { Hedw. }\end{array}$} & $\mathrm{CK}$ & $0.65 \pm$ & - & $0.33 \pm 0.12$ & - & 1.01 & - & 30.9 & - \\
\hline & 6 & $0.52 \pm 0.19$ & $0.65 \pm 0.26$ & $0.25 \pm 0.09$ & $0.29 \pm 0.05$ & $0.76 \pm$ & $0.92 \pm 0.14$ & 86 & $11.22 \pm$ \\
\hline & 12 & $0.52 \pm 0.17$ & $0.69 \pm 0.27$ & $0.26 \pm 0.07$ & $0.26 \pm 0.04$ & $0.72 \pm 0.11$ & $0.74 \pm 0.10$ & 15.01 & $10.03 \pm 1.63$ \\
\hline & 24 & $0.54 \pm 0.15$ & $0.71 \pm 0.25$ & $0.22 \pm 0.06$ & $0.24 \pm 0.06$ & $0.72 \pm 0.14$ & $0.78 \pm 0.09$ & $14.35 \pm 1.38$ & $9.96 \pm 1.02$ \\
\hline & 48 & $0.89 \pm 0.24$ & $0.67 \pm 0.20$ & $0.33 \pm 0.11$ & $0.38 \pm 0.21$ & $0.67 \pm 0.09$ & $0.77 \pm 0.08$ & $10.01 \pm 1.21$ & $9.99 \pm 1.13$ \\
\hline & 72 & $0.92 \pm 0.36$ & $0.68 \pm 0.21$ & $0.35 \pm 0.10$ & $0.35 \pm 0.19$ & $0.64 \pm 0.08$ & $0.70 \pm 0.10$ & $8.73 \pm 1.08$ & $9.97 \pm 1.11$ \\
\hline \multirow{6}{*}{$\begin{array}{l}\text { Erythrodontium } \\
\text { julaceum (Schwaegr.) } \\
\text { Par. }\end{array}$} & $\mathrm{CK}$ & $0.48 \pm 015$ & - & $0.31 \pm 0.19$ & - & $1.03 \pm 0.10$ & - & $27.74 \pm 1.48$ & - \\
\hline & 6 & $0.51 \pm 0.22$ & $0.61 \pm 0.22$ & $0.24 \pm 0.12$ & $0.42 \pm 0.21$ & $1.43 \pm 0.21$ & $0.99 \pm 0.13$ & $16.17 \pm 1.55$ & $18.06 \pm 2.05$ \\
\hline & 12 & $0.39 \pm 0.18$ & $0.53 \pm 0.19$ & $0.19 \pm 0.09$ & $0.17 \pm 0.08$ & $1.03 \pm 0.18$ & $0.74 \pm 0.15$ & $12.48 \pm 1.19$ & $16.28 \pm 1.56$ \\
\hline & 24 & $0.79 \pm 0.31$ & $0.87 \pm 0.26$ & $0.35 \pm 0.21$ & $0.47 \pm 0.24$ & $0.77 \pm 1.12$ & $0.79 \pm 0.12$ & $8.73 \pm 1.21$ & $11.82 \pm 1.43$ \\
\hline & 48 & $0.65 \pm 0.24$ & $0.73 \pm 0.25$ & $0.37 \pm 0.16$ & $0.47 \pm 0.26$ & $0.69 \pm 0.13$ & $0.80 \pm 0.17$ & $2.5 \pm 0.43$ & $14.35 \pm 1.11$ \\
\hline & 72 & $0.85 \pm 0.34$ & $0.90 \pm 0.29$ & $0.38 \pm 0.14$ & $0.41 \pm 0.18$ & $0.67 \pm 0.11$ & $0.74 \pm 0.14$ & $0.62 \pm 0.18$ & $9.35 \pm 1.13$ \\
\hline
\end{tabular}


shows that chlorophyll shows a trend of an initial decline and a later increase as stress aggravates. Our previous article published the influences of drought stress and replenishment on chlorophyll content in Erythrodontium julaceum (Schwaegr.) Par. [24]. Chlorophyll a in Bryum argenteum Hedw. reaches its lowest levels under stress for $24 \mathrm{~h}$, whereas Erythrodontium julaceum (Schwaegr.) Par. [24] and Barbula unguiculata Hedw. reach the lowest chlorophyll a levels under stress for $12 \mathrm{~h}$. The change in chlorophyll b levels shows a similar trend. Chlorophyll a in Bryum argenteum Hedw. is at $0.614 \mathrm{mg} \mathrm{g}^{-1} \mathrm{FW}$ at the beginning, down to $0.429 \mathrm{mg} \mathrm{g}^{-1} \mathrm{FW}$ under stress for $24 \mathrm{~h}$, and goes up to $0.644 \mathrm{mg} \mathrm{g}^{-1} \mathrm{FW}$ under stress for $72 \mathrm{~h}$. Chlorophyll a in Barbula unguiculata Hedw. decreases from $0.653 \mathrm{mg} . \mathrm{g}^{-1} \mathrm{FW}$ at the beginning to $0.515 \mathrm{mg} \mathrm{g}^{-1} \mathrm{FW}$ under stress for $12 \mathrm{~h}$ and increases to $0.917 \mathrm{mg} \cdot \mathrm{g}^{-1} \cdot \mathrm{FW}$ after stress for $72 \mathrm{~h}$, whereas that of Erythrodontium julaceum (Schwaegr.) Par. [24] changes insignificantly, with an inevitable fluctuation. Externally, plants do not show yellowing. The decrease in chlorophyll content is possibly related to the temporary decline in photosynthetic capacity. Moreover, due to significant dehydration, the moss plants curled firmly into hibernation. The decline of chlorophyll content is related to the unit increase of chlorophyll caused by the significantly reduced water content. After rehydration, chlorophyll content is restored to a certain extent under moderate-tomild water stress.

3.3.2. Drought Stress and Rehydration Influence on Changes in Chlorophyll Fluorescence in Three Epilithic Mosses (1) Drought Stress and Rehydration Influence on Changes in $F_{v} / F_{m}$. During the early stages of stress, $F_{v} / F_{m}$ of the three mosses is slowly reduced. As stress aggravates, for Bryum argenteum Hedw. and Barbula unguiculata Hedw., $F_{v} / F_{m}$ decreases significantly in comparison with control group, from 0.763 to 0.240 and from 0.796 to 0.266 , respectively, at the early stage of stress compared to being under stress for $72 \mathrm{~h} . F_{v} / F_{m}$ of Erythrodontium julaceum (Schwaegr.) Par. [24] does not decrease significantly, from 0.753 to 0.552 . After rehydration, $F_{v} / F_{m}$ of the mosses is restored. Barbula unguiculata Hedw. is restored to the highest degree, from 0.266 under stress for $72 \mathrm{~h}$ to 0.607 , followed by Bryum argenteum Hedw., and Erythrodontium julaceum (Schwaegr.) Par. [24] is restored to the lowest degree. The three mosses show a compensation phenomenon in the process of rehydration, wherein $F_{v} / F_{m}$ is higher than those in the corresponding treatment groups. This is mainly because plants will avoid drought through temporary reduction of photosynthesis in adverse conditions. Although plants incur specific damage, they can recover quickly after drought relief. Although the physiological activities of the photosynthetic apparatus are influenced through the relative water content of plant, the relationship between the two is not a simple linear one. From the change in $F_{v} / F_{m}$ among the mosses with relative water content, it can be found (Figure 3) that Barbula unguiculata Hedw. has a strong desiccation tolerance. Before relative water content of plants is reduced to $45 \%, F_{v} / F_{m}$ is almost unchanged as relative water content declines. As such, when the relative content of water is in the range of $45-100 \%, F_{v} / F_{m}$ is relatively constant. Only when the relative water content of plants is lower than $45 \%$ does $F_{v} / F_{m}$ sharply decrease. For Bryum argenteum Hedw. and Erythrodontium julaceum (Schwaegr.) Par., $F_{v} / F_{m}$ is sharply down with relative water content. Relative water content causing $F_{v} / F_{m}$ to suddenly reduce called the threshold value of relative water content causing $F_{v} / F_{m}$ to change. The relative water content threshold of Barbula unguiculata Hedw. is $45 \%$. However, there is no threshold value for Bryum argenteum Hedw. and Erythrodontium julaceum (Schwaegr.) Par. [24] in this paper. This indicates that when relative water content inside Barbula unguiculata Hedw. is more than $45 \%$, the maximal photochemical efficiency will not be affected and photosynthetic organs will be not damaged. But if the water content is beyond this threshold, it will cause damage to plants.

(2) Drought Stress and Rehydration Influence on PS II Quantum Efficiency (Yield) and Electron Transport Rate (ETR). In the early period of stress (in twelve hours), the yields of Erythrodontium julaceum (Schwaegr.) Par. [24] and Barbula unguiculata Hedw. slightly increase and later decrease. It indicates that the adaptation process can be produced in early stages of drought stress and that the photosynthetic system can be restored by itself (yield of Bryum argenteum Hedw. is gradually reduced). Yields of the three mosses at the late stage of stress are significantly reduced $(P<0.05)$. In the early periods of the rehydration, yields of Erythrodontium julaceum (Schwaegr.) Par. [24] and Barbula unguiculata Hedw. increase slightly but are slightly lower compared to the control group. Within 0-48 hours, there is no evident difference compared with control group $(P<0.05)$, but $48 \mathrm{~h}$ later, the difference is significant $(P<0.05)$. After rehydration, the yield of Bryum argenteum Hedw. is slightly restored, but it is lower compared to the control group. As stress aggravates, ETR of the three mosses show the same trend as yield, namely, significant declining. After rehydration, the ETR of 3 mosses are slightly up. For Erythrodontium julaceum (Schwaegr.) Par. [24] and Barbula unguiculata Hedw., the difference with the control group within $48 \mathrm{~h}$ is not significant. $48 \mathrm{~h}$ later, it is slightly restored but not to the control level. During drought stress, the change in PSII actual photochemical efficiency in the mosses is similar to that of $F_{v} / F_{m}$. Dehydration first influences the maximum light-harvesting efficiency of the moss photosynthetic mechanism, which affects the actual photochemical efficiency and then influences its electron transfer chain. When the relative water content of plants is lower than the threshold value, the decline of the actual photochemical efficiency of mosses is caused by the decline in light energy capture and electron transfer rate.

(3) Drought Stress and Rehydration Influence on $q P$ and $q N$. As drought intensifies, $q P$ of the three mosses gradually decline. Erythrodontium julaceum (Schwaegr.) Par. [24] declines in a small range, from 0.958 to 0.950 , with an insignificant difference $(P>0.05)$. Bryum argenteum Hedw. decreased from 0.908 to 0.717 , falling by $21.04 \%$, with a 

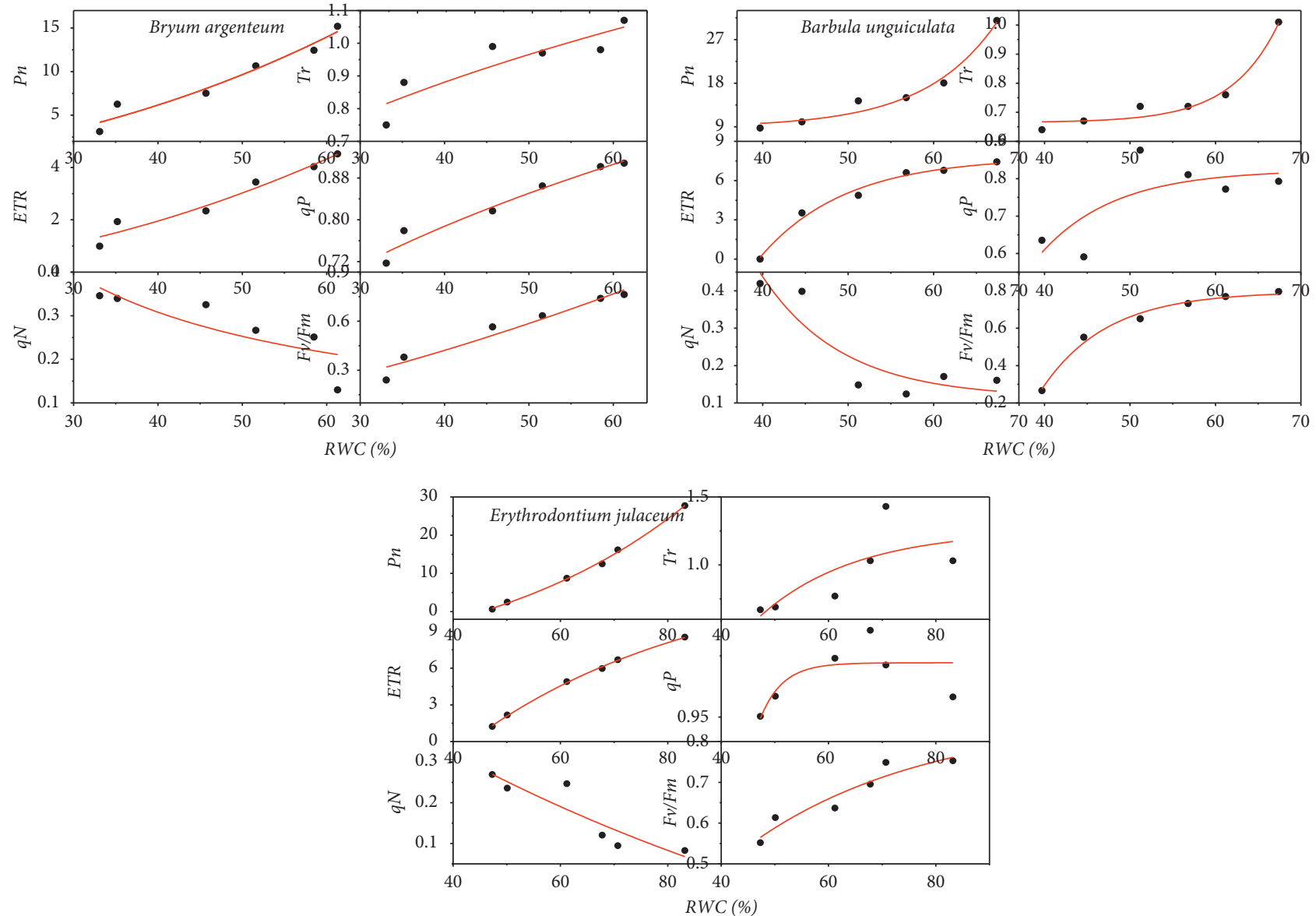

FIGURE 3: Relationship between photosynthesis indexes and RWC in three epilithic mosses during dehydration. Erythrodontium julaceum (Schwaegr.) Par. with permission from [29].

significant difference $(P<0.05)$. For Barbula unguiculata Hedw., it slightly increased at the beginning. This finding represents a drought stress response. It gradually decreased in $12-48 \mathrm{~h}$ and slightly increased $48 \mathrm{~h}$ later, showing a generally increasing trend with three phases. The first and last phases are characterized by an increase interspaced by a second decreasing phase. After rehydration, $q P$ can get a specific increase. Bryum argenteum Hedw. restored more slightly but not to the control level, whereas, for Barbula unguiculata Hedw., it is higher than the control level in 6-12 $\mathrm{h}$, generating a super compensation effect, and then goes lower than the control level. Before $48 \mathrm{~h}$, Erythrodontium julaceum (Schwaegr.) Par. [24] is slightly more than the control level, generating a super compensation effect, and then goes lower than control level, but the change is minimal. The decline in $q P$ shows that the number of open PSII reaction centers is reduced under drought stress, causing a significant reduction in photosynthetic electron transport. $q N$ shows an increasing trend with the duration of water stress. Bryum argenteum Hedw. and Erythrodontium julaceum (Schwaegr.) Par. [24] show a similar trend characterized by an initial slight increase that balances later. But the increase in Bryum argenteum Hedw. is greater than that of Erythrodontium julaceum (Schwaegr.) Par. [24] Barbula unguiculata Hedw., initially increases slightly, followed by a decrease, and concludes with a final sharp increase that is three times higher under severe stress for $72 \mathrm{~h}$, with very significant difference $(P<0.01)$. The increase in $q N$ shows that a large amount of absorbed light energy dissipates by nonphotochemical ways under the condition of water stressinduced photoinhibition. After rehydration, $q N$ can be restored to the normal level. All three mosses varied with relative water content. $q P$ will increase, while $q N$ will decrease with the increase in relative water content (Figures 3 and 4).

\subsubsection{Drought Stress and Rehydration Influence on Photo-} synthesis and Transpiration Rate. The too high or too low water content will decrease net photosynthetic rate [30]. Dilks \& Proctor's research has shown that water membranes with extremely high surface tension would increase the gas exchange resistance and has an inhibitory effect on the photosynthesis of mosses [31]. As a whole, net photosynthetic rates $(P n)$ of the mosses are positively correlated to relative water content. It can be found from Table 2 and Figure 3 that, after a period of drought and dehydration, net photosynthetic rates $(P n)$ in the mosses decline gradually. In normal conditions, the net photosynthetic rate $(P n)$ of Barbula unguiculata Hedw. is the largest at $30.93 \mu \mathrm{mol}$ 

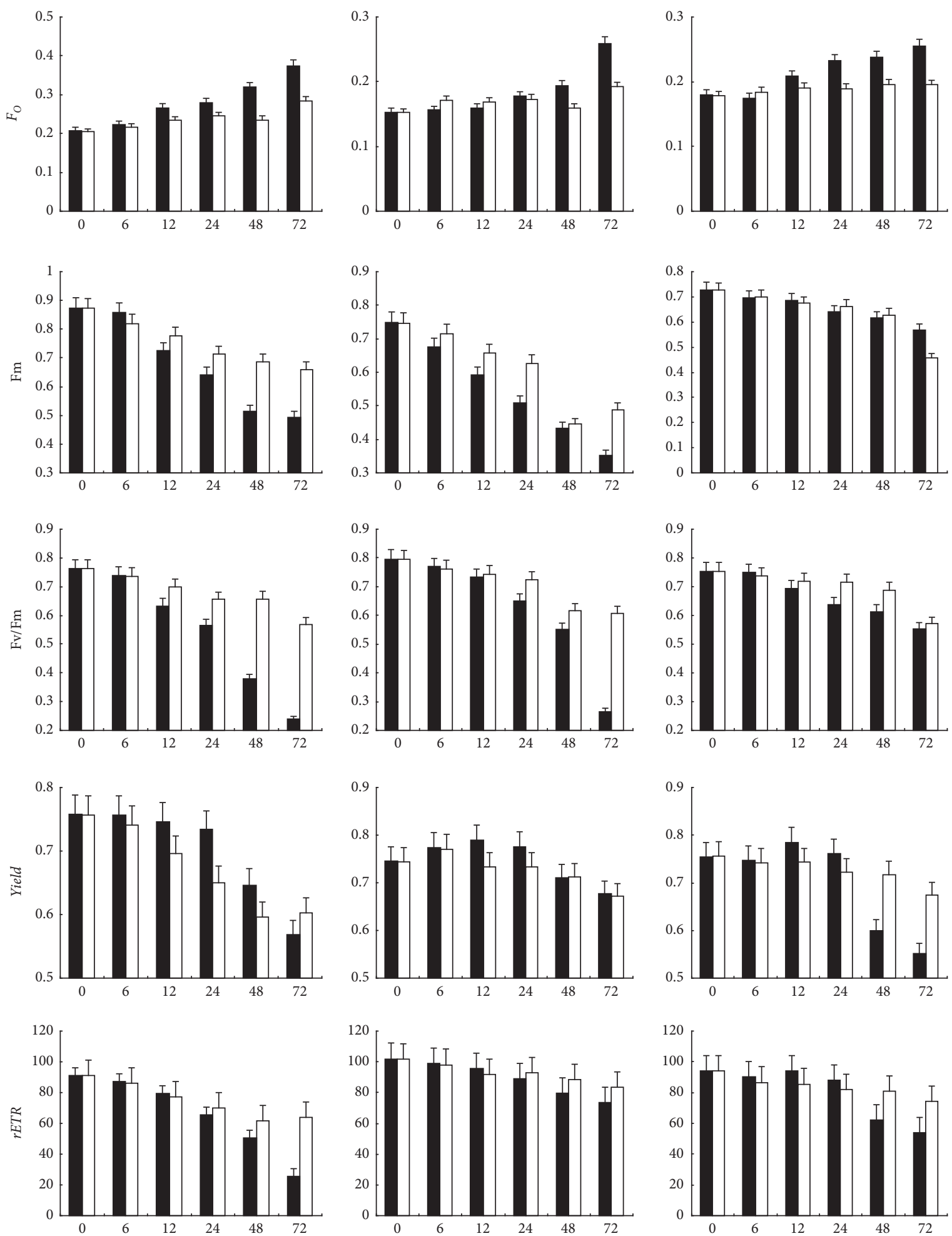

(a)

Figure 4: Continued. 



口 Rewatering

(b)

FIGURE 4: The effect of replenishment and drought stress on chlorophyll fluorescence parameters in three epilithic mosses. Erythrodontium julaceum with permission from [24]. Copyright 2016 open-access from Bangladesh botanical society.

$\mathrm{CO}_{2} \cdot \mathrm{m}^{-2} \cdot \mathrm{s}^{-1}$ and that of Bryum argenteum Hedw. is the smallest at $15.19 \mu \mathrm{molCO}{ }_{2} \cdot \mathrm{m}^{-2} \cdot \mathrm{s}^{-1}$. After 3 days' stress, the net photosynthetic rates $(P n)$ of the three mosses are sharply declined. For Bryum argenteum Hedw., Barbula unguiculata Hedw., and Erythrodontium julaceum (Schwaegr.) Par., it is $3.12 \mu \mathrm{mol} \quad \mathrm{CO}_{2} \cdot \mathrm{m}^{-2} \cdot \mathrm{s}^{-1}, \quad 8.73 \mu \mathrm{mol} \quad \mathrm{CO}_{2} \cdot \mathrm{m}^{-2} \cdot \mathrm{s}^{-1}$, and $0.62 \mu \mathrm{molCO}_{2} \cdot \mathrm{m}^{-2} \cdot \mathrm{s}^{-1}$, respectively, falling by $4.87,3.54$, and 44.74 times. Erythrodontium julaceum (Schwaegr.) Par. is the largest in the declining range, and photosynthesis was seriously affected. After rehydration, the net photosynthetic rate $(P n)$ of Erythrodontium julaceum (Schwaegr.) Par. is restored most greatly, and those of Bryum argenteum Hedw. and Barbula unguiculata Hedw. are restored just slightly. This indicates that dehydration does not cause damage to PS II of plants.

The changes in the transpiration rates of the mosses in the process of dehydration and rehydration are shown in Table 2 and Figure 3. In the beginning, transpiration rates of Bryum argenteum Hedw., Barbula unguiculata Hedw., and Erythrodontium julaceum (Schwaegr.) Par. are, respectively, $1.07 \mathrm{mmol} \mathrm{H}_{2} \mathrm{O} \cdot \mathrm{m}^{-2} \cdot \mathrm{s}^{-1}, \quad 1.01 \mathrm{mmol} \mathrm{H}_{2} \mathrm{O} \cdot \mathrm{m}^{-2} \cdot \mathrm{s}^{-1}$, and $1.03 \mathrm{mmol} \mathrm{H} \mathrm{H}_{2} \mathrm{O} \cdot \mathrm{m}^{-2} \cdot \mathrm{s}^{-1}$. The difference between the species is not obvious $(P>0.05)$. After stressing for $72 \mathrm{~h}$, transpiration rates among the mosses decrease to different extents, but the decrease is not very large. This is related to the characteristic of the moss plants belonging to poikilohydric plants. After rehydration, all mosses are restored to different degrees, but the differences between species and between treatments do not reach a significant level.

3.4. Water Stress on Water Use Efficiency. According to Figure 5, between the mosses, there exists an evident



FIGURE 5: Effects of the drought stress on water use efficiency in three types of epiphytic mosses.

difference in WUE, generally showing a gradual declining trend as stress aggravates. For Bryum argenteum Hedw., WUE is $14.20 \mu \mathrm{molCO}_{2} / \mathrm{mmolH}_{2} \mathrm{O}$ in the expected condition and goes down to $4.16 \mu \mathrm{molCO}_{2} / \mathrm{mmolH}_{2} \mathrm{O}$ after stress for $72 \mathrm{~h}$, falling by 3.14 times. Barbula unguiculata $\mathrm{Hedw}$. decreased from $30.62 \mu \mathrm{molCO}_{2} / \mathrm{mmolH}_{2} \mathrm{O}$ at the beginning to $11.84 \mu \mathrm{molCO}_{2} / \mathrm{mmolH}_{2} \mathrm{O}$ after stress for $72 \mathrm{~h}$, falling by 2.59 times. For Erythrodontium julaceum (Schwaegr.) Par., it decreased from $26.93 \mu \mathrm{molCO}_{2} / \mathrm{mmo} \mathrm{H}_{2} \mathrm{O}$ to $5.32 \mu \mathrm{molCO}_{2} / \mathrm{mmolH}_{2} \mathrm{O}$, falling by 5.06 times. The drought resistance as WUE reflects 
is Barbula unguiculata Hedw.>Erythrodontium julaceum (Schwaegr.) Par. $>$ Bryum argenteum Hedw. Barbula unguiculata Hedw. with higher WUE can more effectively transport energy and water use. In the case of a low water supply level, it can maintain lower transpiration and higher photosynthesis rates.

\section{Discussion}

Berger-Langefeldt divide plants into two ecological types, namely, constant water and variable water, according to the characteristics of the plant water balance. Constant water plants reduce the rate of water loss using stomatal closure to maintain leaves' relatively stable water content. In contrast, variable water plants reduce the rate of water loss using tissue moisture content reduction. Variable water plants are at the cost of tissue water content declining [32]. Generally, bound water content and $V_{s} / V_{a}$ are closely related to drought resistance in plants [32]. When $V_{s} / V_{a}$ is low, plant metabolism is active with fast growth, but the resistance is weak. When $V_{s} / V_{a}$ is high, plant metabolism is inactive with slow growth and with strong resistance. $V_{a}, V_{s}$, and $V_{s} / V_{a}$ of the three mosses changed significantly with the aggravation of water stress, in which $V_{s}$ and $V_{s} / V_{a}$ increased, while $V_{a}$ content decreased. After rehydration, free water increases rapidly and $V_{s} / V_{a}$ ratio decreases. This phenomenon indicates that plants maintain the water balance in the body by adjusting the content of free water and bound water. The lack of water saturation and relative water content of leaves are important indexes to reflect the hydration tension of plants. With the increase of the stress process, RWC showed a trend of decrease in this study. After rehydration, RWC increased to different degrees and WSD dropped to different extents, but the variation was not significant, indicating that rock moss had a certain hysteresis effect on water stress within a relatively short time. The water potential gradient is the driving force to maintain the normal operation of water and water in plants flows from high to low. Erythrodontium julaceum (Schwaegr.) Par. declines most, followed by Barbula unguiculata Hedw., and Bryum argenteum Hedw. declines the least. After rehydration, the water potential of the three species of bryophytes recovered to different extents, indicating that bryophytes in karst areas have intense drought and dehydration tolerance. RWC and water potential of the three mosses are very different, which is consistent with similar studies abroad [33]. The unique geology and geomorphology in the karst area cause the uneven distribution of water; some places are dry perennially, and some are prone to waterlogging. After raining, surface karst water quickly seeps underground, and the ground cannot store rainwater. Therefore, even in areas with abundant rainfall, a special karst seasonal arid environment will be formed, different from the arid environment caused by lack of rainfall in the desert and other environments.

In this paper, chlorophyll contents of three types of crusted mosses generally show a trend of declining first and increasing later with increased stress. This is related to the influence on the plant photosynthetic capacity. This is also related to the increase in chlorophyll content per unit mass, which is due to a large amount of dehydration in the moss sphaerophyta which causes the plant to curl into dormancy, resulting in a substantial decrease in water content. RWC of the mosses is negatively correlated to $q N$ and positively correlated to $F_{v} / F_{m}$, yield, ETR, and $q P$. After rehydration, the fluorescence parameters could be recovered to normal levels under mild-to-moderate stress but could not be recovered under severe stress. Chlorophyll fluorescence characteristics under drought stress of photosynthetic quantum conversion efficiency are low, photosynthetic system II reaction center closed, and once the environment quickly absorbs moisture, it gradually returned to normal metabolism [44]. For example, $F_{v} / F m$ and nonphotochemical quenching $(q P)$ of Rhytidiadelphus loreus can be restored in a short period. It indicates that its photosynthetic system can still work after rehydration [15]. The whole rehydration for Syntrichia caninervis Mitt. can be completed within $3 \mathrm{~m}$. More than 50 percent of the PS II revives, containing oxygen metabolism, excitation energy transfer, electron transfer, charge dislocation, and so on, which can be restored to normal upon rehydration for $0.5 \mathrm{~m}$. If the rehydration is longer, the energy transferring to PS II reaction center tends to balance; at the same time, NPQ is down [34]. $R W C$ is negatively correlated to $q N$ and positively correlated to $F_{v} / F_{m}$, yield, ETR, and $q P$. After rehydration, the fluorescence parameters could be recovered to normal levels under mild-to-moderate stress and could not be recovered under severe stress. It is the same as the changing trends of Syntrichia caninervis Mitt. and Grimmia pilifera P. Beauv. Therefore, after drought stress, rehydrated chlorophyll fluorescence characteristics reflect the adaptability of plants to stress and the corresponding protective mechanism. The studies show that as the water content of Rhytidium rugosum and Rhytidiadelphus triquetrus declines, the dark respiration rate would increase. There is a sudden leaped peak before closing to natural drying, and then it goes down. Myuroclada maximowiczii, Mnium cuspidatum Hedw., and Ptilium crista-castrensis do not have apparent peaks. During rehydration, the respiration rate of moss plants is similar to the photosynthetic rate, with a declining trend. Dry plants do not have significant gas exchange. For these five moss plants, photosynthetic activity can be restored to the original level after water absorption for $24 \mathrm{~h}$. It indicates that the photosynthesis of most of the mosses can be rapidly restored after rehydration [35]. This paper has proved that water use efficiency (WUE) will be constantly down as stress aggravates. At the early stages of stress, the recovery potential of WUE after rehydration is higher than that in the late stage. It is consistent with the result that the respiration rate after rehydration is quicker than the net photosynthetic rate [36].

Epilithic mosses in karst areas are mostly exposed on rock surfaces under drought stress during their growth and even need to endure rapid dehydration stress. A series of the characteristics adaptive to the dry environment are formed in a long-term evolution process. Plants are usually densely pulvinate, clump, or blanket-like moss clump. The water holding ability of capillary system is improved, and the movement of air on the blade's surface is decreased with the 
aim of reducing the water evaporation. During dehydration, the photosynthetic mechanisms of three crusted mosses have strong dehydration-resistant capacity. In a drought environment, the water content in the body can be lowered to survive in a dormant state. Cell integrity and structure are maintained as far as possible to minimize cell injury and metabolites destruction. Once rehydration occurs, physiological metabolic activity can be quickly recovered. During rehydration, the repair mechanism is quickly triggered for the repair of photosynthetic mechanism resulting from dehydration [37]

\section{Data Availability}

The data used to support the results of this work can be obtained from the associated authors upon request.

\section{Conflicts of Interest}

The authors declare no conflicts of interest.

\section{Acknowledgments}

This work was supported by funds from the National Natural Science Foundation (Grant no. 41463006) and the Science and Technology Foundation of Guizhou Province (Qiankehe Foundation [2017] 1001).

\section{References}

[1] L. Rong, S. J. Wang, G. S. Yu, X. Deng, and J. Ran, "Stable isotope analysis of water sources of four woody species in the libo karst forest," Scientia Silvae Sinicae, vol. 48, no. 7, pp. 14-22, 2012.

[2] Y. Tao and Y. Zhang, "Effects of leaf hair points on dew deposition and rainfall evaporation rates in moss crusts dominated by Syntrichia caninervis, Gurbantunggut desert, northwestern China," Acta Ecologica Sinica, vol. 32, no. 1, pp. 7-16, 2012.

[3] Y. M. Zhang, "Microstructure and development characters in early stage of biological soil crust of desert," Chinese Science Bulletin, vol. 50, no. 1, pp. 42-47, 2005.

[4] A. Khandelwal, S. H. Cho, H. Marella et al., "Role of ABA and ABI3 in desiccation tolerance," Science, vol. 327, no. 5965, p. 546, 2010.

[5] C. Cabot, J. V. Sibole, J. Barceló, and C. Poschenrieder, "Lessons from crop plants struggling with salinity," Plant Science, vol. 226, pp. 2-13, 2014.

[6] M. Benassi, L. R. Stark, J. C. Brinda, D. N. McLetchie, M. Bonine, and B. D. Mishler, "Plant size, sex expression and sexual reproduction along an elevation gradient in a desert moss," The Bryologist, vol. 114, no. 2, pp. 277-288, 2011.

[7] I. Herrnstadt and G. J. Kidron, "Reproductive strategies of Bryum dunense in three microhabitats in the Negev Desert," The Bryologist, vol. 108, no. 1, pp. 101-109, 2005.

[8] D. H. Vitt, "Patterns of growth of the drought tolerant moss, Racomitrium microcarpon, over a three year period," Lindbergia, vol. 15, no. 6, pp. 181-187, 1989.

[9] W. C. Oechel and W. T. Lawrence, "Taiga," Physiological Ecology of North American Plant Communities, Chapman and Hall, New York, NY, USA, pp. 66-94, 1985.
[10] L. M. Collier and E. H. Pinn, "An assessment of the acute impact of the sea lice treatment ivermectin on a benthic community," Journal of Experimental Marine Biology and Ecology, vol. 230, no. 1, pp. 131-147, 1998.

[11] K. A. Santarius, "Apoplasmic water fractions and osmotic potentials at full turgidity of some Bryidae," Planta, vol. 193, no. 1, pp. 32-37, 1994.

[12] R. Beckett, "Pressure-volume analysis of a range of poikilohydric plants implies the existence of negative turgor in vegetative cells," Annals of Botany, vol. 79, no. 2, pp. 145-152, 1997.

[13] M. C. F. Proctor, Z. Nagy, Z. Csintalan, and Z. Takacs, "Watercontent components in bryophytes: analysis of pressurevolume relationships," Journal of Experimental Botany, vol. 49, no. 328, pp. 1845-1854, 1998.

[14] M. Proctor, "Water-relations parameters of some bryophytes evaluated by thermocouple psychrometry," Journal of Bryology, vol. 21, no. 4, pp. 263-270, 1999.

[15] Z. Csintalan, M. C. F. Proctor, and Z. Tuba, "Chlorophyll fluorescence during drying and rehydration in the mosses Rhytidiadelphus loreus (Hedw.) Warnst.,Anomodon viticulosus (Hedw.) hook. \& tayl. and Grimmia pulvinata (Hedw.) Sm," Annals of Botany, vol. 84, no. 2, pp. 235-244, 1999.

[16] W. E. Seel, N. R. Baker, and J. A. Lee, "Analysis of the decrease in photosynthesis on desiccation of mosses from xeric and hydric environments," Physiologia Plantarum, vol. 86, no. 3, pp. 451-458, 1992.

[17] V. I. Deltoro, A. Calatayud, C. Gimeno, A. Abadía, and E. Barreno, "Changes in chlorophyll a fluorescence, photosynthetic $\mathrm{CO}_{2}$ assimilation and xanthophyll cycle interconversions during dehydration in desiccation-tolerant and intolerant liverworts," Planta, vol. 207, no. 2, pp. 224-228, 1998.

[18] M. Marschall and M. C. F. Proctor, "Desiccation tolerance and recovery of the leafy liverwort Porella platyphylla (L.) Pfeiff.: chlorophyll-fluorescence measurements," Journal of Bryology, vol. 21, no. 4, pp. 257-262, 1999.

[19] Z. Csintalan, Z. Takács, C. Michael, F. Proctor, Z. Nagy, and Z. Tuba, "Early morning photosynthesis of the moss Tortula ruralis following summer dew fall in a Hungarian temperate dry sandy grassland," Plant Ecology, vol. 151, no. 1, pp. 51-54, 2000 .

[20] J. Zhang, Y. M. Zhang, A. Downing, N. Wu, and B. C. Zhang, "Photosynthetic and cytological recovery on remoistening Syntrichia caninervis Mitt., a desiccation-tolerant moss from Northwestern China," Photosynthetica, vol. 49, no. 1, pp. 13-20, 2011.

[21] X. Q. Zhang, S. J. Wang, and M. Sun, “The drought stress and rehydration influence on chlorophyll fluorescence characteristics of Barbula fallax Hedw. in areas of karst rocky desertification: case study near Huaxi district, Guiyang City," Carsologica Sinica, vol. 33, no. 1, pp. 77-81, 2014.

[22] X. Q. Zhang, L. Zhang, Y. J. He, X. Y. Feng, and M. Sun, "Water uptake mechanism and desiccation-tolerant adaptation of Taxiphyllum aomoriense crust in karst rocky desertification," Acta Ecologica Sinica, vol. 30, no. 12, pp. 3108-3116, 2010.

[23] Y.-H. Wu, G.-D. Cheng, and Q. Gao, "Bryophyte's ecology functions and its significances in revegetation," Journal of Desert Research, vol. 23, no. 3, pp. 215-220, 2003.

[24] X. Zhang, "Effects of drought stress and rehydration on chlorophyli fluorescence characteristics of Erythrodontium julaceum (schwaegr.) PAR. In areas of puding karst rock 
desertification," Bangladesh Journal of Botany, vol. 45, no. 4, pp. 911-917, 2016.

[25] Z. Zhang, Experiment Guidance for of Plant Physiology, Higher Education Press, Beijing, China, 2009, in Chinese, 4 edition.

[26] X. L. Liu, L. H. Gao, and M. C. Liu, "Improvement on measurement of free water and bound water in plant tissues," China Vegetables, vol. 1, no. 4, pp. 9-11, 2005.

[27] W. K. Bao and L. Leng, "Determination methods for photosynthetic pigment content of bryophyte with special relation of extraction solvents," Chinese Journal of Applied and Environmental Biology, vol. 11, no. 2, pp. 235-237, 2005.

[28] Y. L. Song, L. L. Sun, and Z. Shu, "Effects of drought stress and rehydration on chlorophyll fluorescence characteristics in leaves of invasive Wedelia trilobata," Acta Ecologica Sinica, vol. 29, no. 7, pp. 3713-3721, 2009.

[29] X. Zhang, T. Liu, and C. Cong, "Effect of alternating wettingdrying on physiological features of water content and photosynthesis of Erythrodontium julaceum (Schwaegr.) Par. in karst habitat," Carsologica Sinica, vol. 38, no. 6, pp. 901-909, 2019.

[30] J. Zhang and Y. M. Zhang, "Effects of freezing and thawing on chlorophyll fluorescence of Syntrichia caninervis in biological soil crusts," Journal of Desert Research, vol. 31, pp. 1479-1487, 2011.

[31] T. J. K. Dilks and M. C. F. Proctor, "Photosynthesis, respiration and water content in bryophytes," New Phytologist, vol. 82, no. 1, pp. 97-114, 1979.

[32] S. Shi, Y. Wang, H. Zhou, and J. Zhou, "Comparative analysis of water related parameters and photosynthetic characteristics in the endangered plant Tetraena mongolica Maxim. and the closely related Zygophyllum xanthoxylon (Bunge) Maxim," Acta Ecologica Sinica, vol. 32, no. 4, pp. 1163-1173, 2012.

[33] M. C. F. Proctor, "The bryophyte paradox, tolerance of desiccation, evasion of drought," Plant Ecology, vol. 151, no. 1, pp. 41-49, 2000.

[34] Y. Li, G. Wang, T. H. Xu et al., "Reorganization of photosystem II is involved in the rapid photosynthetic recovery of desert moss Syntrichia Caninervis upon rehydration," Journal of Plant Physiology, vol. 167, no. 6, pp. 390-391 397, 2010.

[35] L. J. Tang, S. H. Yang, J. H. Lin, T. Cao, and Q. Gao, "Effects of desiccation and rehydration on the $\mathrm{CO}_{2}$ assimilation and respiration of bryophytes in the Changbai mountains," Chinese Journal of Applied and Environmental Biology, vol. 4, no. 1, pp. 6-9, 1998.

[36] Y. D. Liu, J. Li, J. Chen, and T. Cao, "Net photosynthetic rate of two species of wintering host mosses for gullaphids and its response to light, temperature and water content," Chinese Journal of Applied Ecology, vol. 11, no. 5, pp. 687-692, 2000.

[37] J. D. Bewley, "Physiological aspects of desiccation tolerance," Annual Review of Plant Physiology, vol. 30, no. 1, pp. 195-238, 1979. 